\title{
A Study on the Second Class Construction System of University Library under the Background of General Education
}

\author{
Lina Li \\ Library and Information Center, Heilongjiang Bayi Agricultural University, Daqing, China \\ Email: byndcscy@126.com
}

How to cite this paper: Li, L.N. (2018) A Study on the Second Class Construction System of University Library under the Background of General Education. Journal of Service Science and Management, 11, 650-656.

https://doi.org/10.4236/jssm.2018.116044

Received: October 25, 2018

Accepted: December 25, 2018

Published: December 28, 2018

Copyright $\odot 2018$ by author and Scientific Research Publishing Inc. This work is licensed under the Creative Commons Attribution International License (CC BY 4.0).

http://creativecommons.org/licenses/by/4.0/

\begin{abstract}
University library is an extension of class teaching, and it is more flexible educationally. The library plays its role of the second class mainly through three ways: First, it is to carry out the work of the second class in the university library; second, it is to make full use of the "second resources" in the university library; and the third is to create the best learning atmosphere in the university library. Through the study of the construction system of the second classroom in University libraries, we can better enhance the service ability of the library for undergraduate teaching.
\end{abstract}

\section{Keywords}

University Library, Second Classroom, Construction System

\section{Introduction Background}

In the Rules of Library in Colleges and Universities newly issued by the Ministry of Education of China on December 31, 2015, it is pointed out that "libraries should fully participate in the training of talents in schools, give full play to the role of the second class, and improve the comprehensive quality of students by various means".

And under the mode of training talents by general education, innovation and entrepreneurship education, besides scientific research, extracurricular academic activities, autonomous learning, etc., the functions of library are also manifested in its support for a rich mixture of campus cultural activities, because it has quite a lot of hidden curriculum resources, and offers abundant reading resources, good reading environment and targeted reading guidance for the healthy growth and self-improvement of college students. Meanwhile, the key point to the con- 
struction of the second class supplementary to undergraduate education is making full use of all kinds of rich academic resources of the library to improve students' reading literacy and lay a solid foundation for success [1].

\section{Making Full Use of Resources to Carry out Extracurricular Activities}

Under the mode of general education, library becomes the second class of college students with its rich resources and humanistic environment. And compared with the first class, which is dominated by teachers and classroom, the second class is a two-way and independent learning process, in which, the library needs to play a guiding role and deliver excellent spiritual food to college students [2]. While reading is the most critical factor in general education, libraries should actively explore the establishment of three-dimensional reading promotion mode to guide students to have correct reading habits [3]. First of all, libraries should give full play to the advantages of traditional libraries and recommend relevant books to students of different types and grades. Secondly, libraries should use new media to promote reading and actively study how to use new media to provide guidance services for students. Finally, libraries can promote reading through various activities. For example, they can launch reading promotion activities in World Reading Day, diversify reading forms of students and extend the connotation of reading by organizing lectures, real person library, photography reading, knowledge competition and other activities [4].

\subsection{Weeding out the Conservative Idea}

Libraries should take the initiative to attract students, make them love the library, be willing to read, constantly improve their comprehensive quality, perfect and supplement the content of school education. And on the basis of providing students with a good learning environment and excellent reader services, it is also necessary for them to carry out colorful reading education activities and strengthen the cultivation of reading appreciation and analysis ability.

\subsection{Guiding Students to Read and Raising Their Humanistic Quality}

Fostering good moral characters, the ideal of working hard for their career, strong will and professionalism of students. Letting students gain positive energy of human civilization, set up correct ideals and values, warn against the extreme individualism tendency of blindly worshiping money and pursuing personal pleasure, have the confidence and determination to realize the China dream by hard study, help and care each other through various forms of reading guidance. Providing readers with a variety of accesses to knowledge and information, such as having a reading day, book fair, art exhibition, academic or knowledge lectures, seminars, etc.

Recommending books to students regularly. For example, in the weekly book recommendation activity, recommendation and guidance are given on 
special books in combination with current events, festivals and special periods of time. In addition, we can also encourage excellent students to recommend books in combination with the activity of excellent evaluation and appraisal; invite famous teachers to recommend books; recommend books based on the borrowing data of all kinds of readers; recommend targeted books in combination with large-scale activities on campus. Guiding classical reading. Offering elective course on reading literacy. Changing current education mode, in which, teaching dominates, and guiding students to turn from one-way infusion learning to active learning of self exploration, mutual communication and research. In this process, the library can provide independent learning space and seminar room, and subject librarians can participate in the whole teaching process to provide help and services for teachers and students. Guiding classical reading through targeted, meaningful and close to readers' reading activities. Organize reading promotion activities. Introducing the growth experience of scientists, inventors and artists in the world to students through special lectures, speeches, training classes, exhibitions and other forms to stimulate their enthusiasm for learning and help them set up a correct outlook on life and values. Purifying campus cultural atmosphere by organizing set excellent book reading activities, review of Chinese and foreign classics, reading speech activities, etc. for college students. Guiding students to read, and improving their reading quality by setting up "New Book Report Column", "Special Book Recommendation Column", "Hot-Spot Book Review and Introduction Column" or publishing "Guiding Tabloid". Keeping close contact with students, attaching importance to and supporting the journalist communicating activities organized by student associations, such as literary salons and science \& technology associations. And subject librarians should give specific guidance. Inviting well-known experts and scholars to the university for lectures on holidays and anniversaries as "May 1", "July 1 ", "October 1" to have patriotic education and enhance the sense of mission and responsibility of college students to make people richer and the country stronger. Carrying out reading activities via new media and technologies. Since digital reading is popular among college students born in the "90s" and "00s", the advantages of WeChat public platform of the library can be taken to carry out online reading promotion activities with flexible forms and strong operability, such as collecting and selecting book reviews, soliciting stories related to reading and library, collecting recitation works, and launching series of reading sharing sessions, a book reading salon, real person library, etc. While attracting and guiding readers to read the recommended books, encouraging readers to transpond them actively so as to effectively achieve the goal of reading promotion.

\subsection{Arousing the Enthusiasm of All Parties to Create a Good Atmosphere for Reading}

Arousing the enthusiasm of such four parties as students, teachers, librarians and managers, letting readers read actively, stimulating readers' reading interest, 
mining the reader's reading desire and developing readers' reading habit to let them have internal impetus to read, and turn reading into an indispensable activity in their life. Only with good reading habits can college students have the ability of self-study cultivated and improved to broaden the knowledge taught in class and have better scientific and cultural qualities. Furthermore, it enables students to have the ability to analyze and solve problems, be skillful at their own work in practice, and become practical talents with initiative and creativity.

\section{Improving the Construction of Library Team and Guaranteeing the Construction Quality of the Second Class}

Walking into a library is more than simply borrowing, reading and returning books. In this process, the type of books is required to adapt to teaching and scientific research, so as to meet the needs of different majors and levels. Librarians are required to have high cultural literacy and a variety of service capabilities. And the service quality is fundamental for the existence and development of university libraries. Without high-quality service, it is difficult to incarnate the existence value of university libraries and give play to the role of libraries in teaching services. Improving the service quality of librarians can effectively improve the service quality of a library, which concretely reflects librarians' professional ethics, knowledge accomplishment, psychological quality, working ability and other comprehensive qualities in the service process. The service quality of librarians has a direct impact on the service quality and overall image of a library. Therefore, librarians should meet the requirements of the positioning, nature and task of the library, comprehensively raise their ideological and moral level and professional ability, and improve the quality of teaching service. As librarians, we must always bear in mind the university's management philosophy and motto spirit, and integrate these excellent management philosophy and motto spirit into our daily work [5].

Ideologically, we should establish such service concepts as "being enthusiastic for readers", "service oriented" and "readers first", treat readers' affairs as our own, and let readers feel like bathing in spring breeze in the library. In knowledge learning, librarians should keep pace with the times and establish the concept of "never too old to learn". In daily life, we should not only constantly improve our professional knowledge of library information, but also learn knowledge of computer, psychology, management and other related fields, so as to inject new blood into the work of book management and serve in an innovative way. At work, we should learn to summarize and improve, constantly accumulate work experience and improve our ability to respond to new situations, complex problems and emergencies, so as to ensure that the library works in a normal and orderly manner. It is an urgent task for university library to improve the service level and quality. And it requires librarians to keep learning and improving to meet the needs of the university. As a result, librarians should go to the base course teaching units and secondary colleges of the university to know the teaching plan and content of the college, and give ear to the opinions and sug- 
gestions of teachers and students.

\section{Creating a Good Humanistic Environment and Raising the Construction Level of the Second Class}

The necessary humanistic care of librarians is an important factor to enhance the habitual reading environment dependence. And the essence of humanistic care is to respect people's dominant position and individual difference, care about people's rich and diverse individual needs, stimulate people's initiative, enthusiasm and creativity, and promote people's free, all-round and healthy development. First of all, libraries shall establish the correct concept of humanistic care, transform from "book-based", "library-oriented" and "emphasizing the importance of collection over use" to "people-oriented" and "emphasizing both collection and use". Secondly, it is necessary to enrich the cultivation methods and skills of humanistic care consciousness, and pay attention to the key points to be cared about in different stages of pre-reading, reading and post-reading; and in pre-reading stage, targeted services shall be provided focusing on the interest and motivation, personality and characteristics of readers. However, in reading stage, care should be given to the degree of reader's information sensitivity, focus and the degree of information memory. And in post-reading stage, focuses shall be mainly on readers' feedback, proposals and suggestions, rethinking, association, etc. All in all, we should turn "passive and closed services" into "active and open services", and "indoctrination" into "absorption". Finally, the evaluation system of humanistic care consciousness cultivation should be established and perfected to evaluate the cultivation of humanistic care in university libraries by relatively scientific, rational and fair standards, so as to promote the internalization and practice of the concept of "humanistic care".

The construction of humanistic environment aims at meeting readers' needs beyond reading itself and letting them maintain a good mood. Reading environment is one of the key points for the educational environment in colleges and universities. And "to create the best reading environment, show the best service feature and provide the best reading quality" for "satisfying readers, staffs and the university" has always been the goal of the library. And there are two aspects to create an ideal humanistic environment: one refers to the interpersonal environment, which is reflected in the spirit of librarians. To do well in education through service, the words and deeds of librarians can show whether they have professional qualities, professional ethics, normative professional behaviors, professional knowledge and skills. While establishing professional ethics, we should have the idea of "readers first" and actively welcome every reader with a warm attitude. In terms of professional behavior, we shall avoid the use of linguistic taboo, and always remember polite service language to standardize our words and deeds, and teach by example and model. In providing professional consultation, we should familiarize ourselves with the collections, get to know the readers and serve as the reading adviser for the readers through our professional quality and knowledge structure. The other is the creation of reading en- 
vironment, namely, the aesthetic or green layout of reading environment. Because harmonious greening ornament and appropriate aesthetic decoration can not only bring readers a tranquil and pleasant experience, but fully meet the needs of reading and make document retrieval and application more efficient.

\section{Conclusion}

As we all know, library is a school's thesaurus and literature information center. Through the books and reference materials, it can not only help students get improved greatly in professional field, increase the students' knowledge during their use of the library, or make up for the deficiency caused by narrow scope of professional knowledge, improve their ability to study, analyze and solve problems independently, but cultivate their ability of independently acquiring knowledge and retrieving literature information. What's more, the large amount of literature and information resources in the library breaks the spatio-temporal limit at class, broadens students' horizon, activates their thinking, stimulates their creation consciousness and improves their innovation ability. Thus, library plays an important role in the enrichment of knowledge, the cultivation of practical and independent thinking ability, the stimulation and cultivation of learning enthusiasm and innovation ability of college students [6].

\section{Funded}

This paper is a research projects of Heilongjiang Provincial Department of Culture Provincial Art Planning Project "Research on Cultural Construction in Rural Revitalization Strategy” (Project Number: 2018D024); Heilongjiang Bayi Agricultural University Intramural subject of "Application and Research of Micro Platform in Library Information Service” funded by (Project Number: XRW2014-18).

\section{Conflicts of Interest}

The author declares no conflicts of interest regarding the publication of this paper.

\section{References}

[1] Ye, Q. (2018) Innovation of Reading Promotion in Colleges and Universities Based on "Second Classroom" System. Management Observer, 29, 136-138+141.

[2] Zhou, W.Z. (2017) Paying Attention to the Construction of Reading Environment and Improving the Positive Role of Readers in the Second Classroom. Inner Mongolia Science Technology \& Economy, 22, 159-161.

[3] Wang, X.G. (2017) Challenges Faced by University Libraries under General Education Environment. China Management Informationization, 22, 186-187.

[4] Lu, Z.P. and Su, W.C. (2015) An Empirical Study on Tacit Knowledge Transfer in the Second Classroom of University Library. Library and Information Service, 13, 42-52.

[5] Zhang, L. and Zhou, J. (2014) Constructing the Teachers' Team and Making Good 
L. N. Li

Use of the Second Classroom of the Library. The Library Journal of Shandong, 1 , 63-65+69.

[6] Li, Y.P. (2014) On the Promoting Role of University Libraries in the Growth of College Students. Science \& Technology Vision, 13, 235+237. 